\title{
Hotspot analysis of Taiwanese breeding birds to determine gaps in the protected area network
}

\author{
Tsai-Yu Wu', Bruno A Walther ${ }^{2,3}$, Yi-Hsiu Chen ${ }^{1}$, Ruey-Shing Lin ${ }^{4}$ and Pei-Fen Lee ${ }^{1,5^{*}}$
}

\begin{abstract}
Background: Although Taiwan is an important hotspot of avian endemism, efforts to use available distributional information for conservation analyses are so far incomplete. For the first time, we present a hotspot analysis of Taiwanese breeding birds with sufficient sampling coverage for distribution modeling. Furthermore, we improved previous modeling efforts by combining several of the most reliable modeling techniques to build an ensemble model for each species. These species maps were added together to generate hotspot maps using the following criteria: total species richness, endemic species richness, threatened species richness, and rare species richness. We then proceeded to use these hotspot maps to determine the $5 \%$ most species-rich grid cells (1) within the entire island of Taiwan and (2) within the entire island of Taiwan but outside of protected areas.

Results: Almost all of the species richness and hotspot analyses revealed that mountainous regions of Taiwan hold most of Taiwan's avian biodiversity. The only substantial unprotected region which was consistently highlighted as an important avian hotspot is a large area of unprotected mountains in Taiwan's northeast (mountain regions around Nan-ao) which should become a high priority for future fieldwork and conservation efforts. In contrast, other unprotected areas of high conservation value were just spatial extensions of areas already protected in the central and southern mountains. To combine the results of our four hotspot criteria, we assessed which grid cells were the most valuable according to all four criteria. Again, we found the Nan-ao mountain regions to be important. We also showed that different hotspot criteria only partially overlapped and sometimes barely at all.

Conclusions: Therefore, to protect areas based on only one hotspot criterion (total species richness) would not protect areas based on other hotspot criteria (endemic species richness, threatened species richness, or rare species richness) in Taiwan.
\end{abstract}

Keywords: Hotspots; Biodiversity; Conservation priorities; GIS; Distribution modeling

\section{Background}

The conservation of biodiversity has gained increasing attention from both the public and decision-makers because biodiversity is the basis for functioning ecosystems and the life-support system of the earth (Millennium Ecosystem Assessment 2005; Walther et al. 2011a). At the same time, all levels of biodiversity are rapidly eroding (Butchart et al. 2010).

In response to these challenges, one important concern of conservation biology is to locate biodiversity hotspots because it is an effective way to protect a large number of

\footnotetext{
* Correspondence: leepf@ntu.edu.tw

${ }^{1}$ Institute of Ecology and Evolutionary Biology, National Taiwan University, Taipei 106, Taiwan

${ }^{5}$ Biodiversity Research Center, National Taiwan University, Taipei 106, Taiwan Full list of author information is available at the end of the article
}

species within functional landscapes (Myers et al. 2000). The concept of 'biodiversity hotspots' was first developed by Myers (1988) and has since blossomed into a large body of local, regional, and global analyses (Myers et al. 2000; Ceballos and Ehrlich 2006; Garcia 2006; Grenyer et al. 2006; Callicott et al. 2007; Schouten et al. 2010).

The definition of a hotspot has been intensely debated; for example, hotspots could be defined as those areas with the highest species richness including all species (Samson and Knopf 1993; Williams et al. 1996; Kerr 1997; Myers et al. 2000; Orme et al. 2005; Grenyer et al. 2006) or only endemic species (Kerr 1997; Orme et al. 2005), rare species (Prendergast et al. 1993; Grenyer et al. 2006; Williams et al. 1996), or threatened species (Dobson et al. 1997; Orme et al. 2005; Grenyer et al. 2006). Many of these hotspot analyses used birds (Williams et al. 1996; Ho 2005; Orme et al. 
2005; Chen 2007; Jenkins et al. 2010) because they are relatively easy to monitor over large areas. Therefore, avian datasets are often the most comprehensive in terms of both spatial and temporal coverages.

Taiwan is an important hotspot of endemism for many different taxa, including birds (Shao et al. 2008). More than 570 bird species have been recorded throughout Taiwan, including several outlying islands (Chinese Wild Bird Federation 2010). On the island of Taiwan proper, 145 species were reported as breeding birds (Fang 2008), among which, at least 17 species (12\%) are considered endemic to Taiwan (Chinese Wild Bird Federation 2010). Over the last two decades, basic information on avian distributions and ecology has increased through records by both amateur and professional observers. Using this newly available information, Severinghaus (1994) published the first study of avian zoogeography and the first comprehensive avifauna for Taiwan (Severinghaus et al. 2010). Lee et al. (1998) created the first $2 \times 2-\mathrm{km}$ distributional database to analyze the relationship between environmental factors and avian distributions (Nieh 1999; Huang 2001; Koh et al. 2006a,b). Further studies focused on species richness patterns in local regions (Hsu et al. 2004; Ko 2004; Peng 2008), Taiwan's mountains (Shiu and Lee 2003), or all of Taiwan (Lee et al. 2004) but without using distribution modeling. Early modeling techniques were used to study bird distributions in local regions (Huang 2001; Koh et al. 2006a,b) or of a single species or subfamily (Liao 1997; Ko et al. 2009a). Ho (2005) and Ding et al. (2006) selected avian biodiversity hotspots and studied bird species richness patterns in East Asia but did not focus on Taiwan. So far, the only hotspot analysis using Taiwan's birds was restricted to 14 endemic bird species (Ko et al. 2009b).

Therefore, we herein present the first hotspot analysis of all of the Taiwanese breeding birds with sufficient sampling coverage for distribution modeling, using these models to generate hotspot maps of total, endemic, threatened, and rare species richness.

\section{Methods}

\section{Study area}

Our study area is the island of Taiwan which spans latitudes $22^{\circ}$ to $25^{\circ} 18^{\prime} \mathrm{N}$ and longitudes $120^{\circ}$ to $122^{\circ} 27^{\prime} \mathrm{E}$ (with a maximum elevation of $3,952 \mathrm{~m}$ ) which can be roughly divided into an almost flat western plain, which has been highly modified by humans, and mountainous areas of central and eastern Taiwan which comprise almost $65 \%$ of the island and are much less developed and in some parts almost inaccessible to humans. The climate ranges from tropical in the south to subtropical in the north and alpine in the high mountains (with an island-wide mean annual temperature of $18^{\circ} \mathrm{C}$ and average annual precipitation of $2,510 \mathrm{~mm}$ ). The natural vegetation is almost exclusively forest, except at high elevations and on river floodplains. We divided this study area into a total of 36,022 grid pixels of $1 \times 1 \mathrm{~km}$ in size.

\section{Species data}

We selected the 145 breeding bird species listed for the island of Taiwan (Fang 2008) and determined each species' endemic and conservation status (Wu et al. 2013). We collated spatiotemporal data from various field studies, including Taiwan's Breeding Bird Survey and studies conducted within the national parks to build the first comprehensive distributional dataset of Taiwan's 145 breeding bird species (more details given in Walther et al. 2011b). We then restricted records to the months of March to July, which is the main breeding season of most species. We also a priori excluded the White Wagtail Motacilla alba from all analyses because it is not possible to visually distinguish breeding individuals from wintering visitors.

For each species, we then coded each $1 \times 1-\mathrm{km}$ grid cell as either present (presence recorded $\geq 1$ visit) or absent (absence recorded $\geq 5$ visits). Finally, we excluded those species for which $<30$ grid cells had been coded as present because distribution models usually do not perform well at low sample sizes (Hernandez et al. 2006; Wisz et al. 2008) which left us with 116 species (Wu et al. 2013).

\section{Environmental data layers}

A much more detailed account of the building of each species' distribution model is given in the studies of Walther et al. (2011b) and Wu et al. (2013). The distribution models were used in the latter paper to reassess each species' conservation status; in this study, we used the same distribution models to determine species richness hotspots. To briefly summarize, we built distributional models for each of the selected 116 bird species using 120 environmental gridded data layers compiled by the Spatial Ecology Lab of National Taiwan University (for details, see Lee et al. 1997). All layers covered the entire island of Taiwan with 36,022 grid pixels at $1 \times 1 \mathrm{~km}$. For our analysis of hotspots outside of protected areas (Figure 1), we used shape files of each of Taiwan's protected areas which were created by the same lab in December 2010 (which were categorized into high, medium-to-high, and low-to-high protection depending on the severity of protection; see Wu et al. 2013 for details).

We then used three steps to reduce the layers and build each species' distribution model from the original 120 layers. First, we chose a relevant subset of layers for each bird species based on their habitat choices (Fang 2008). We then used a two-tailed $t$ test for each of the selected layers to test for a significant association with the presence or absence of the species using a significance level $p<0.05$ and 


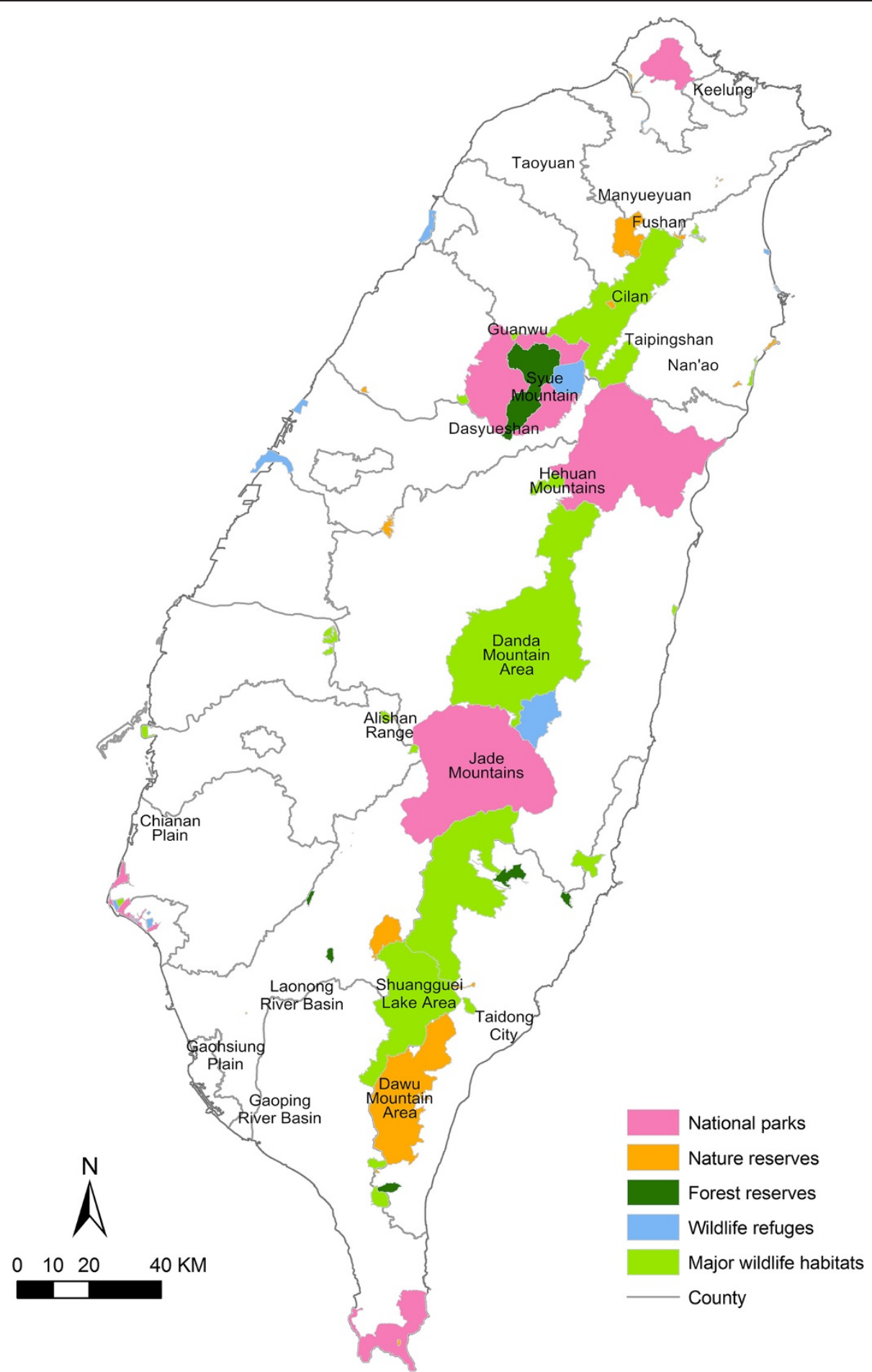

Figure 1 Map of Taiwan's protected areas. All location names mentioned in this study are English transcriptions of the original Mandarin names.

retained only significantly associated variables. We finally eliminated correlated variables using the unweighted pair group method with arithmetic mean tree in the ecological niche factor analysis (ENFA) program (Hirzel et al. 2002).

\section{Building distribution models}

We briefly describe below the four steps used to build the presence-absence distribution for each species (for more details, see Walther et al. 2011b; Wu et al. 2013). 
First, we produced five probabilistic distribution models using the following methods: multiple discriminant analysis (Johnson and Wichern 2007), logistic regression (Austin 2002), genetic algorithm for rule-set production (Stockwell et al. 2006), an ENFA (Hirzel et al. 2002), and maximum entropy (Phillips et al. 2006). Each method was used to model each species' distribution using 50\% of all presence and $50 \%$ of all absence records (training data) and then evaluated the remaining $50 \%$ of presence and absence records (test data). Dividing the data randomly into training and testing data is a prerequisite for calculating evaluation metrics such as MaxKappa and the area under the operating characteristic curve (AUC) score (Fielding and Bell 1997). Second, we ranked the performance of the five models for each species using the AUC score. Third, we produced an ensemble model for each species using a variant of the frequency histogram method (Figure one in Araújo and New 2007) by summing up the three best performing models for each species based on their respective AUC scores. To add up the three models, we chose the MaxKappa threshold recommended by Freeman and Moisen (2008) to turn the probability surface of each model into a binary presence-absence map (resulting in a distribution map for each species coded $0,1,2$, or 3 ). We then re-coded codes 0 and 1 into absence and codes 2 and 3 into presence. Fourth, we deleted overpredictions for 11 of the 116 species by comparing the modeled distributions with published distribution maps (Severinghaus et al. 2010). Overprediction occurs when a distribution model extends a species' range into areas where the species has never been observed (Walther et al. 2007; 2010). Any region of Taiwan where the species had never been observed was converted into absence using a variety of appropriate shape files (elevation, ecoregions, counties).

The final presence-absence map for each species is shown in $\mathrm{Wu}$ et al. (2013). Using these final maps, we subdivided species into four quartile categories whereby first, second, third, and fourth quartile species corresponded to the modeled distribution of respective species covering $0 \%-25 \%, 25 \%-50 \%, 50 \%-75 \%$, and $75 \%-$ $100 \%$ of all pixels in our study area.

\section{Mapping hotspots}

We generated hotspot maps using the following 'hotspot criteria': total species richness (all species included), endemic species richness (only species with full endemic species status included), threatened species richness (only endangered, rare and valuable, and other conservation-dependent species included), and rare species richness (only first quartile species included). The four hotspot criteria were equally weighted in all of our overlapping analyses. We did not map hotspots for the seven Taiwanese breeding species which are globally threatened according to the IUCN criteria (Fairy Pitta Pitta nympha and Taiwan Bulbul Pycnonotus taivanus listed as 'Vulnerable' and five species as 'Near Threatened, see IUCN 2011) because they are all included in the species listed as threatened within Taiwan. Therefore, they were just a small subset of all threatened bird species within Taiwan. Given that this is a countryspecific analysis, we decided to include all threatened birds as defined for Taiwan.

\section{Results and discussion \\ Results \\ Hotspot analyses}

We generated one presence-absence 'final map' for each species which we then combined to generate one species richness map and two types of hotspot maps for each of the four hotspot criteria as follows:

1. A species richness map for each hotspot criterion was created by simply adding up the final maps of all species which were included in the hotspot criterion.

2. The first type of hotspot analysis was generated by turning the species richness maps into hotspot maps by categorizing grid cells into either hotspot (most species rich) or not, whereby we selected the top $5 \%, 10 \%, 15 \%, 20 \%$, and $25 \%$ most species-rich grid cells. However, each grid cell has a fixed species richness which is an integer value. Therefore, there were usually a lot of grid cells with the same values, making it impossible to select the exact percentage (e.g., 5\%) of grid cells. Instead, we selected a threshold for species richness which was just below the given percentage to ensure that all of the depicted grid cells conformed to our hotspot definition (for more details, see Table 1).

3. The second type of hotspot analysis was generated in essentially the same way, but this time, we excluded all grid cells which fell inside protected areas of Taiwan. Thus, we were able to determine those grid cells which would add the most valuable grid cells to the already established protected areas. In this case, we decided to deal with the same values by choosing a threshold for species richness which was just above a certain percentage (e.g., 5\%) to ensure that no grid cells which were valuable for future protection were missed (for more details, see Table 1).

\section{Total species richness}

We first mapped the total species richness for all of mainland Taiwan (Figure 2a). Overall, areas with high species richness corresponded to higher elevation areas, while low-elevation areas had lower species richness. 
Table 1 Number of grid cells which fulfilled various hotspot criteria

\begin{tabular}{|c|c|c|c|c|c|c|c|c|c|c|}
\hline & \multicolumn{5}{|c|}{ Hotspot criteria } & \multicolumn{5}{|c|}{ Hotspot criteria outside of protected areas } \\
\hline & $\begin{array}{l}\text { Top } \\
5 \%\end{array}$ & $\begin{array}{l}\text { Top } \\
10 \% \\
\end{array}$ & $\begin{array}{l}\text { Top } \\
15 \%\end{array}$ & $\begin{array}{l}\text { Top } \\
20 \%\end{array}$ & $\begin{array}{l}\text { Top } \\
25 \%\end{array}$ & $\begin{array}{l}\text { Top } \\
5 \%\end{array}$ & $\begin{array}{l}\text { Top } \\
10 \% \\
\end{array}$ & $\begin{array}{l}\text { Top } \\
15 \% \\
\end{array}$ & $\begin{array}{l}\text { Top } \\
20 \% \\
\end{array}$ & $\begin{array}{l}\text { Top } \\
25 \%\end{array}$ \\
\hline \multicolumn{11}{|l|}{ Total species richness } \\
\hline $\begin{array}{l}\text { Species richness threshold of selected grid } \\
\text { cells }\end{array}$ & $\geq 74$ & $\geq 71$ & $\geq 69$ & $\geq 67$ & $\geq 65$ & $\geq 70$ & $\geq 66$ & $\geq 63$ & $\geq 59$ & $\geq 56$ \\
\hline Selected number of grid cells & 1,472 & 3,245 & 4,856 & 6,583 & 8,373 & 2,201 & 4,006 & 5,560 & 7,697 & 9,190 \\
\hline Percent of total study area & $4.1 \%$ & $9.0 \%$ & $13.5 \%$ & $18.3 \%$ & $23.2 \%$ & $6.1 \%$ & $11.1 \%$ & $15.4 \%$ & $21.4 \%$ & $25.5 \%$ \\
\hline \multicolumn{11}{|l|}{ Endemic species richness } \\
\hline $\begin{array}{l}\text { Species richness threshold of selected grid } \\
\text { cells }\end{array}$ & $\geq 14$ & $\geq 14$ & $\geq 13$ & $\geq 13$ & $\geq 12$ & $\geq 12$ & $\geq 11$ & $\geq 9$ & $\geq 8$ & $\geq 7$ \\
\hline Selected number of grid cells & 1,519 & 1,519 & 5,266 & 5,266 & 7,656 & 2,647 & 3,647 & 6,824 & 8,810 & 10,344 \\
\hline Percent of total study area & $4.2 \%$ & $4.2 \%$ & $14.6 \%$ & $14.6 \%$ & $21.3 \%$ & $7.4 \%$ & $10.1 \%$ & $18.9 \%$ & $24.5 \%$ & $28.7 \%$ \\
\hline \multicolumn{11}{|l|}{ Threatened species richness } \\
\hline $\begin{array}{l}\text { Species richness threshold of selected grid } \\
\text { cells }\end{array}$ & $\geq 23$ & $\geq 22$ & $\geq 21$ & $\geq 20$ & $\geq 19$ & $\geq 21$ & $\geq 18$ & $\geq 16$ & $\geq 14$ & $\geq 12$ \\
\hline Selected number of grid cells & 1,577 & 3,514 & 5,161 & 6,655 & 8,049 & 2,036 & 4,231 & 6,091 & 7,826 & 9,472 \\
\hline Percent of total study area & $4.4 \%$ & $9.8 \%$ & $14.3 \%$ & $18.5 \%$ & $22.3 \%$ & $5.7 \%$ & $11.8 \%$ & $16.9 \%$ & $21.7 \%$ & $26.3 \%$ \\
\hline \multicolumn{11}{|l|}{ Rare species richness } \\
\hline $\begin{array}{l}\text { Species richness threshold of selected grid } \\
\text { cells }\end{array}$ & $\geq 15$ & $\geq 13$ & $\geq 12$ & $\geq 10$ & $\geq 9$ & $\geq 9$ & $\geq 8$ & $\geq 7$ & $\geq 6$ & $\geq 5$ \\
\hline Selected number of grid cells & 229 & 3,398 & 4,826 & 6,459 & 7,905 & 2,855 & 4,566 & 6,060 & 7,766 & 9,684 \\
\hline Percent of total study area & $0.6 \%$ & $9.4 \%$ & $13.4 \%$ & $17.9 \%$ & $21.9 \%$ & $7.9 \%$ & $12.7 \%$ & $16.8 \%$ & $21.6 \%$ & $26.9 \%$ \\
\hline
\end{tabular}

The most species-rich grids were concentrated in the northeastern (northern Syue Mountain (Mt.), e.g., Manyueyuan, Fushan; northern Central Mountain Range (CMR), e.g., Nan-ao, Cilan, and Taipingshan) and south central mountains (Alishan Range, Jade Mt., southern CMR, e.g., Shuangguei Lake area and North Dawu Mt. areas) (Figure 2b). Focusing on the most species-rich grid cells outside of protected areas revealed that most of the unprotected areas were again found in the northeastern (northern Syue Mt. and the northern CMR, e.g., Nan-ao) and south central mountains (Alishan Range, southern part of Jade Mt., southern CMR) (Figure 2c).

\section{Endemic species richness}

Again, the highest concentration of endemic species was found in mountainous areas (Figure 3a). The most species-rich grids were concentrated mostly in the south central mountains (Alishan Range, Jade Mt., southern CMR, e.g., Shuangguei Lake and North Dawu Mt. areas), with scattered grids also found in the north (Guanwu, Syue Mt., Dasyue Mt., Nan-ao, Hehuan Mt., and the Danda Mt. areas) (Figure $3 \mathrm{~b}$ ). Focusing on the most species-rich grid cells outside of protected areas revealed a somewhat similar distribution to that for total species richness but with additional grid cells selected in the northwestern (northwestern Syue Mt., e.g., Guanwu) and central mountain areas (east side of the CMR) (Figure 3c).

\section{Threatened species richness}

For species threatened within Taiwan, we lumped the three threat categories (endangered, rare and valuable, and other conservation-dependent species) together because their respective richness maps were very similar (Figure $4 \mathrm{a}$ ). The most species-rich grids were mostly concentrated in the south central mountains (Alishan Range, Jade Mt., and southern CMR), with scattered grids also found in the north (Guanwu, Syue Mt., Dasyue Mt., Nan-ao, Hehuan Mt., and Danda Mt. areas) (Figure 4b). The most speciesrich grid cells outside of protected areas were almost all found in mountainous areas that are unprotected (Figure 4c).

\section{Rare species richness}

Mapping rare species displayed a more complex picture (Figure 5a); besides mountainous areas, low-lying areas in 

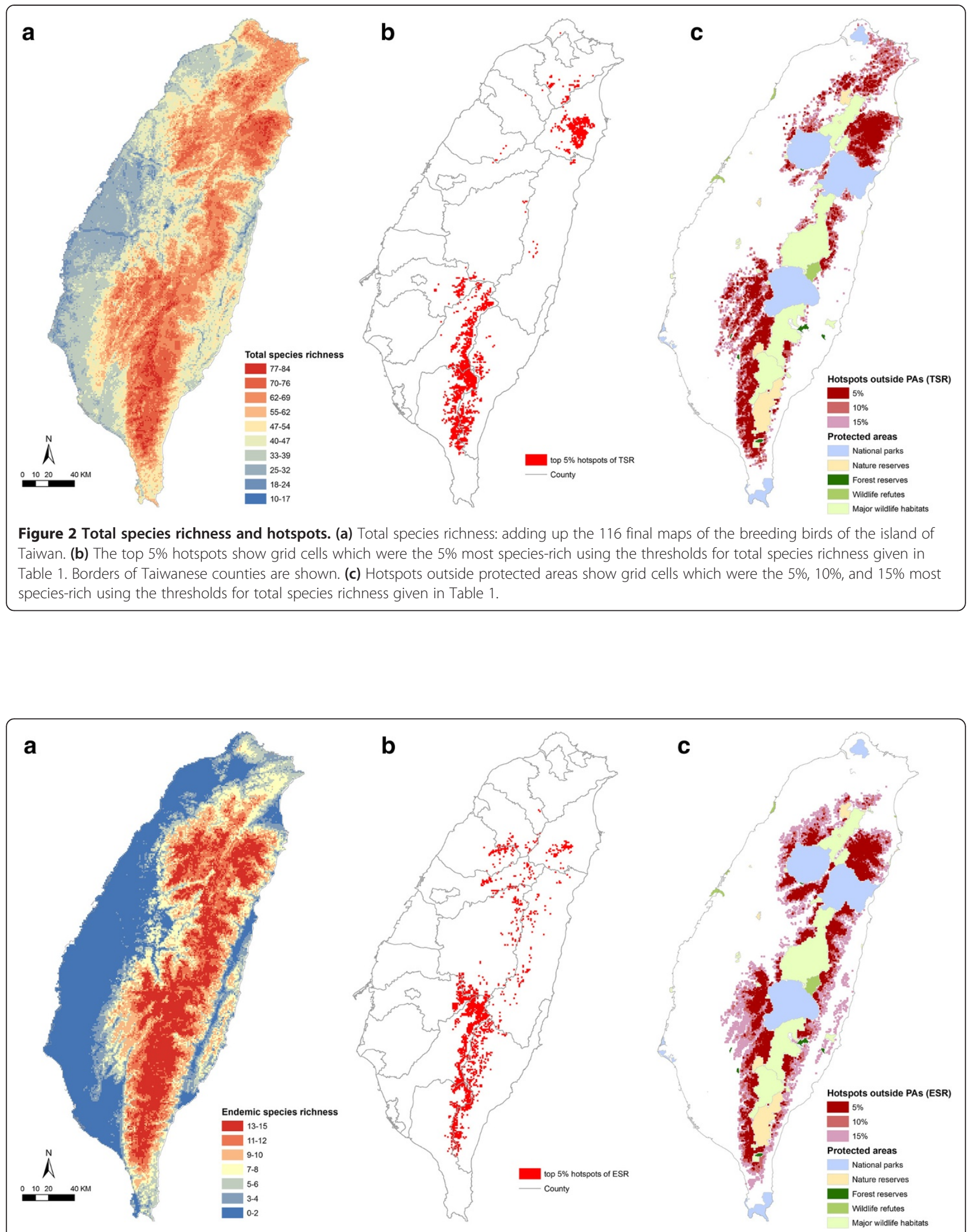

Figure 3 Endemic species richness and hotspots. (a) The endemic species richness was determined by adding up the 16 final maps out of the 17 endemic birds of the island of Taiwan. (b) Top 5\% hotspots and (c) hotspots outside of protected areas (specifics as described in Figure 2). 


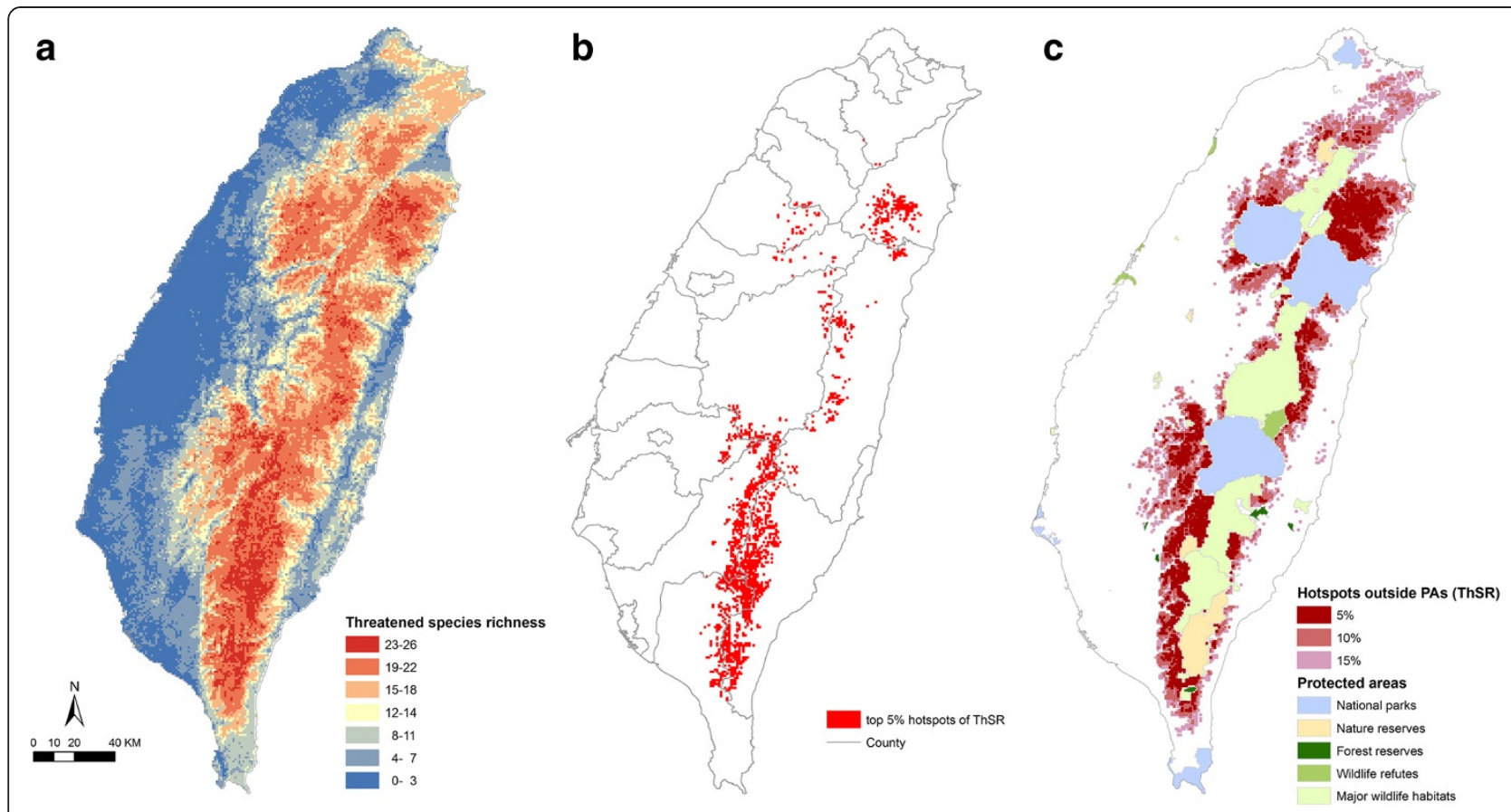

Figure 4 Threatened species richness and hotspots. (a) The threatened species richness was determined by adding up the 31 final maps of the 49 threatened birds of the island of Taiwan (see details in Wu et al. 2013). (b) Top 5\% hotspots and (c) hotspots outside of protected areas (specifics as described in Figure 2).
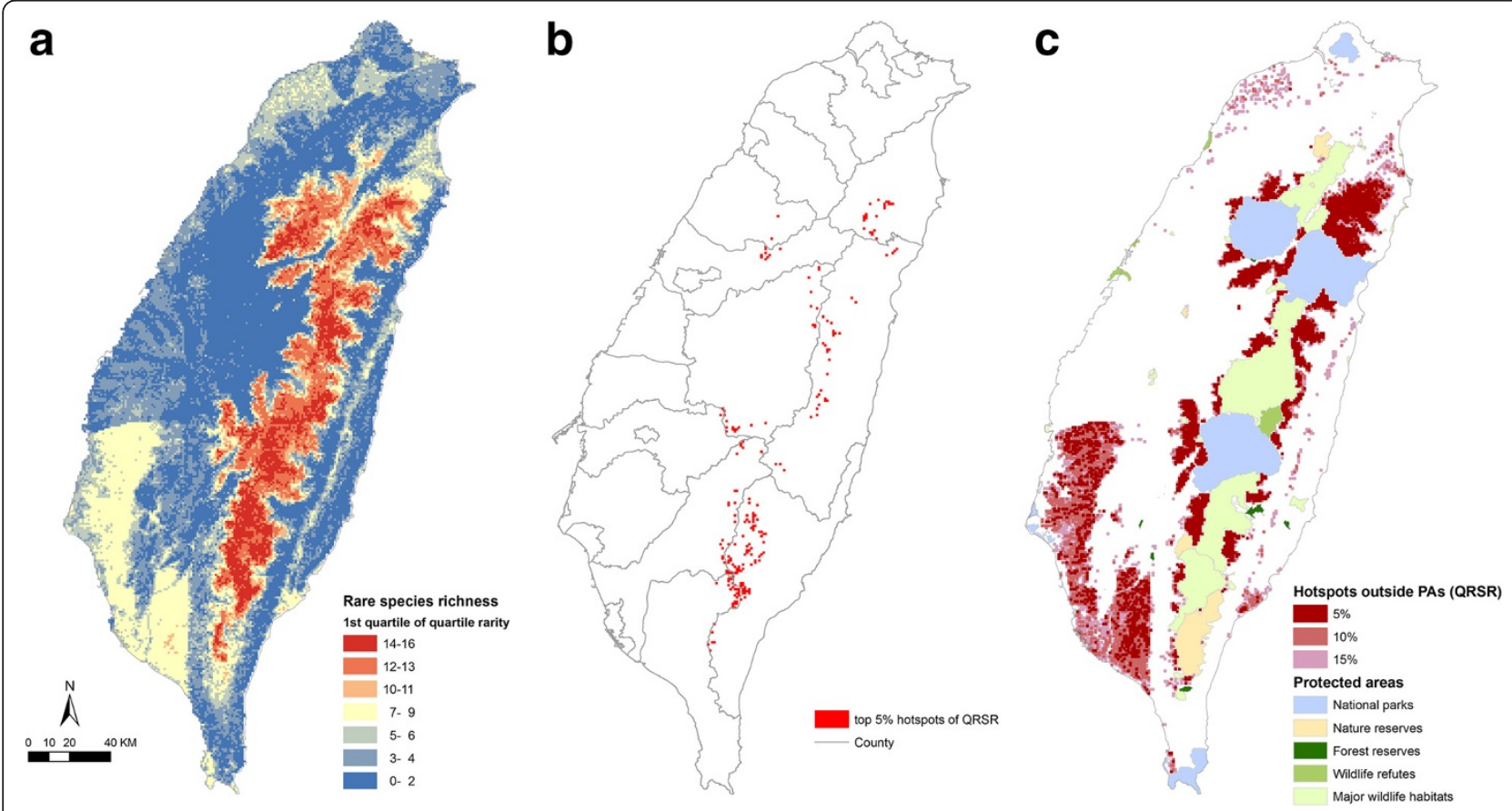

Figure 5 Rare species richness and hotspots. (a) The rare species richness was determined by adding up the 29 final maps of the first quartile birds of the island of Taiwan (see details in Wu et al. 2013). (b) Top 5\% hotspots and (c) hotspots outside of protected areas (specifics as described in Figure 2). 
the northeast (Keelung), northwest (Taoyuan), southwest (Chianan Plain and Gaoping River Basin) and the southern tip (Taitung City), and the longitudinal valley near the southeastern coast were also important. The most speciesrich grids were scattered in various mountainous regions (Dasyue Mt., Nan-ao, Hehuan Mt., Danda Mt. area, Alishan Range, Jade Mt., Shuangguei Lake area, and North Dawu Mt.; Figure 5b). Focusing on the most species-rich grid cells highlighted a region in the southwest (Chianan Plain, Kaohsiung Plain, and Laonong River Basin) which was selected in addition to the usual mountainous regions (Figure 5c).

\section{Combining and comparing hotspot analyses}

We finally combined the results for our four hotspot criteria to assess which grid cells were the most valuable according to all four criteria.

For the first analysis, we included only those grid cells which were the $5 \%$ most species-rich (as depicted in middle panels of Figures 2, 3, 4, and 5). Simply adding up these four hotspot maps yielded Figure 6 which contains two distinct clusters of valuable grid cells in the northeastern (Nan-ao) and south central mountains (southern CMR). For the second analysis, we also

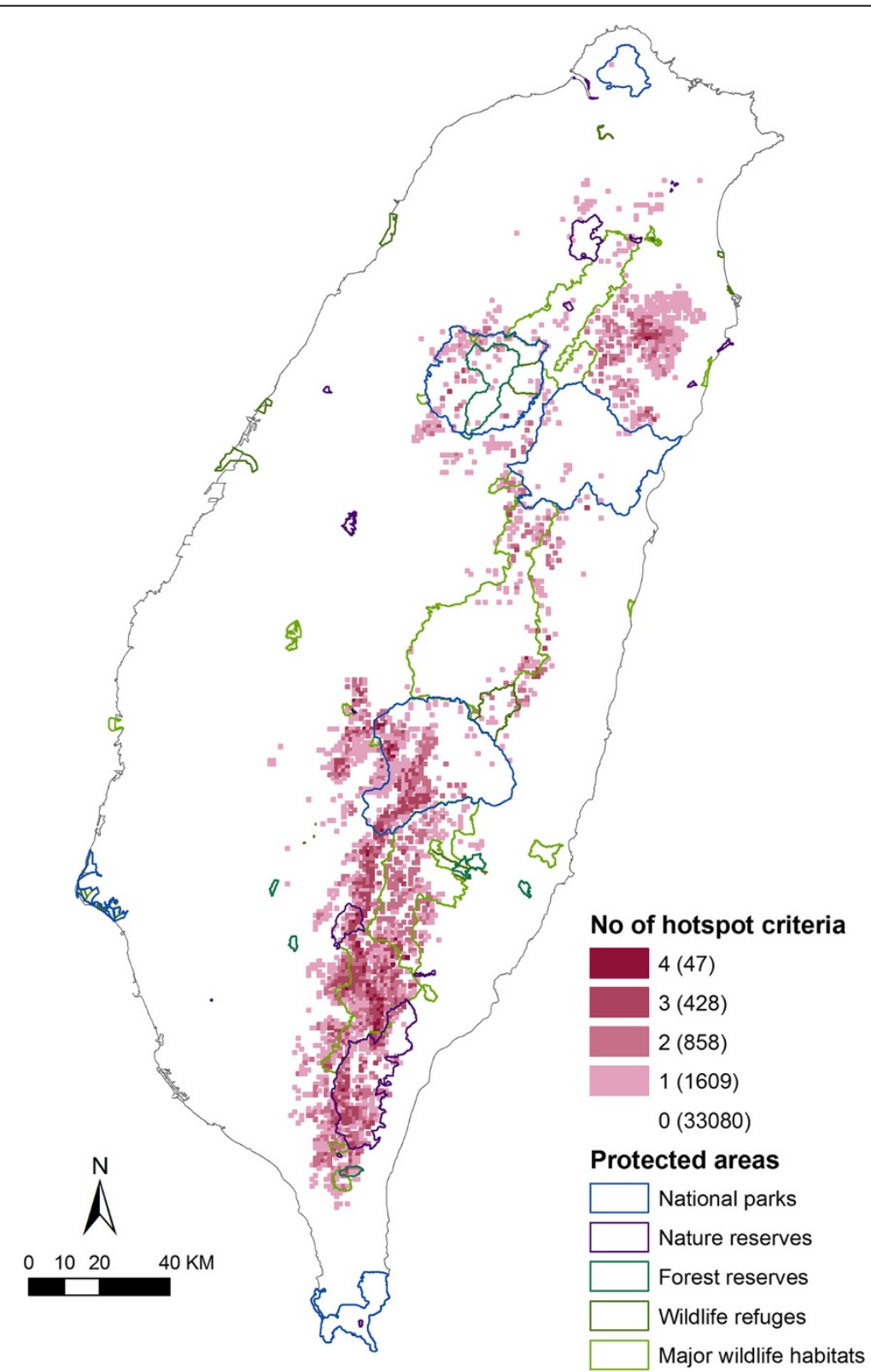

Figure 6 Map of combined four hotspot criteria (middle panels of Figures 2, 3, 4, and 5) in Taiwan. Colors range from dark red (all four hotspot criteria fulfilled) to pink (only one of four hotspot criteria fulfilled). The number of grid cells which qualify for each category of combination hotspots is given in parentheses (see also Tables 1 and 2). The outlines of Taiwan's protected areas are also shown (see Figure 1). 
selected the top 5\% most species-rich grid cells but $a$ priori excluded those cells within protected areas (as depicted in the right panels of Figures 2, 3, 4, and 5), which yielded Figure 7; it contained the same two clusters as in the previous analysis but also included two smaller clusters in the northwestern (Syue Mt.) and central mountains (central region of the CMR, e.g., Hehuan Mt. and Danda Mt.).

We then calculated the percentage coverage of these combined hotspot criteria by the protected area network of Taiwan (Table 2). National parks covered $<20 \%$ of each of the four hotspot criteria (column 3, Table 2). However, these percentages improved quite considerably to $27.0 \%-39.3 \%$ and $48.5 \%-87.2 \%$ for medium-to-high and low-to-high protection areas (columns 7 and 9 in Table 2), respectively. Therefore, a considerable percentage of the best avian hotspots were covered by protected areas, as illustrated in Figure 6.

While the above analyses showed that those grid cells where different hotspot criteria overlap were reasonably

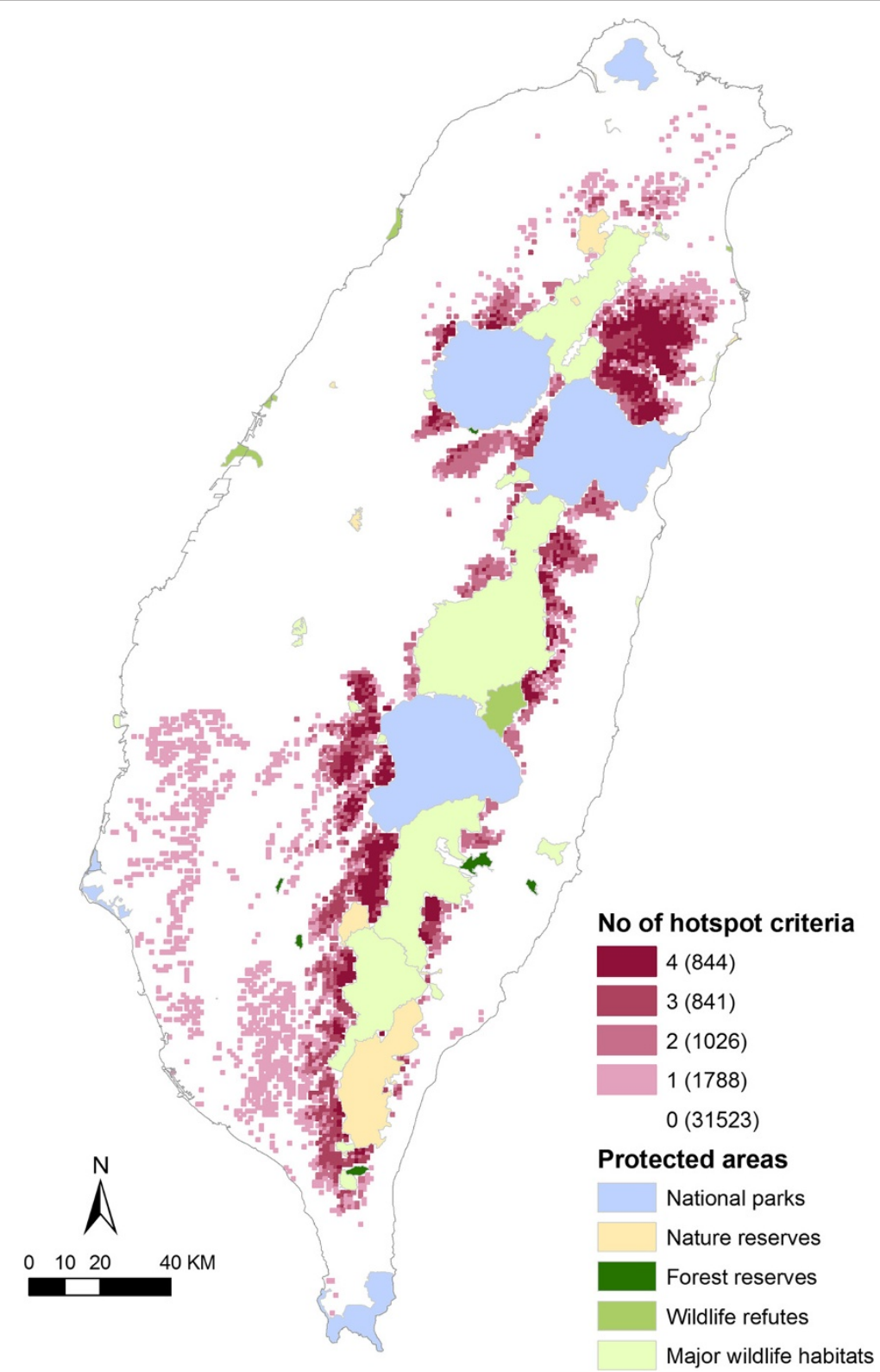

Figure 7 Map of combined four hotspot criteria (right panels of Figures 2, 3, 4, and 5) in Taiwan. These hotspot criteria are the top 5\% hotspots shown in the right panels of Figures 2, 3, 4, and 5 across the island of Taiwan but outside of protected areas. Colors range from dark red (all four hotspot criteria fulfilled) to pink (only one of four hotspot criteria fulfilled). The number of grid cells which qualify for each category of combination hotspots is given in parentheses (see also Table 1). The outlines of Taiwan's protected areas are also shown (see Figure 1). 
Table 2 Number of grid cells within the study area that fulfilled the four hotspot criteria

\begin{tabular}{|c|c|c|c|c|c|c|c|c|}
\hline $\begin{array}{l}\text { Hotspot } \\
\text { criteria fulfilled }\end{array}$ & $\begin{array}{l}\text { Grid cells within } \\
\text { the study area }\end{array}$ & $\begin{array}{l}\text { Highest protection, } \\
\text { i.e., national parks }\end{array}$ & $\begin{array}{l}\text { Nature } \\
\text { reserves }\end{array}$ & $\begin{array}{l}\text { Forest } \\
\text { reserves }\end{array}$ & $\begin{array}{l}\text { Wildlife } \\
\text { refuges }\end{array}$ & $\begin{array}{l}\text { Medium-to-high } \\
\text { protection }\end{array}$ & $\begin{array}{l}\text { Major wildlife } \\
\text { habitats }\end{array}$ & $\begin{array}{l}\text { Low-to-high } \\
\text { protection }\end{array}$ \\
\hline 4 & 47 & $8(17.0 \%)$ & $6(12.8 \%)$ & $0(0.0 \%)$ & $0(0.0 \%)$ & $14(29.8 \%)$ & $28(59.6 \%)$ & 41 (87.2\%) \\
\hline 3 & 428 & 82 (19.2\%) & $84(19.6 \%)$ & $2(0.5 \%)$ & $0(0.0 \%)$ & 168 (39.3\%) & 143 (33.4\%) & 306 (71.5\%) \\
\hline 2 & 858 & 109 (12.7\%) & $110(12.8 \%)$ & 12 (1.4\%) & $5(0.6 \%)$ & $232(27.0 \%)$ & 437 (38.1\%) & $529(61.7 \%)$ \\
\hline 1 & 1,609 & $290(18.0 \%)$ & $129(8.0 \%)$ & $22(1.4 \%)$ & $20(1.2 \%)$ & $438(27.2 \%)$ & 416 (25.9\%) & 781 (48.5\%) \\
\hline 0 & 33,080 & 3,066 (9.3\%) & $561(1.7 \%)$ & $350(1.1 \%)$ & $389(1.2 \%)$ & 3,965 (12.0\%) & 3,191 (9.7\%) & 6,583 (19.9\%) \\
\hline Total & 36,022 & 3,555 & 890 & 386 & 414 & 4,817 & 4,817 & 8,240 \\
\hline
\end{tabular}

Columns 3 to 9 show how many of the grid cells of column 2 fell within the various protected area categories, followed by the percentages in brackets (e.g., for hotspot criterion 4, eight of a total of 47 grid cells (17.0\%) were inside national parks). Note that the highest protection level (i.e., national parks) plus nature reserves, forest reserves, and wildlife refuges was defined as medium-to-high protection and that the addition of major wildlife habitats was then defined as low-to-high protection (see the 'Methods' section for details).

well protected, it is also important to establish how much these four different hotspot criteria overlapped (Table 3). For example, only 512 grid cells of the total of 36,022 grid cells for the entire study area (1.4\%) were hotspots for both total and endemic species richness (upper right triangle in Table 3). These 512 grid cells accounted for $34.8 \%$ of the hotspot grid cells of total species richness $(1,472$, see Table 1$)$ and for $33.7 \%$ of the hotspot grid cells of endemic species richness $(1,519$, see Table 1). The overlap between total, endemic, and threatened species richness was also around 50\%, but the overlap with rare species richness ranged widely, from $3.9 \%$ to $82.5 \%$. Repeating this analysis for the $5 \%$ most species-rich grid cells outside of protected areas (lower left triangle in Table 3), we found much higher overlap percentages, ranging from $33.2 \%$ to $83.1 \%$.

To further analyze the extent of congruence between the four hotspot criteria, we calculated overlaps of all possible combinations of criteria (Table 4). Among the 2,942 grid cells which fulfilled at least one hotspot criterion, only $1.60 \%$ (47 grid cells) fulfilled all four criteria (Table 4, Figure 6). Percentage increases for increasingly fewer hotspot criteria fulfilled were $14.55 \%, 29.16 \%$, and $54.69 \%$, respectively (Table 4 ).

\section{Discussion}

Species distribution models have become an important tool in conservation biology because they usually allow a much better approximation of the true species distribution than the old-fashioned dot or range maps. This is especially important for hotspot analyses where false absences due to undersampling substantially bias the results. Given that some of Taiwan's most valuable habitats are almost inaccessible to humans and therefore most certainly undersampled (Wu et al. 2013), the use of distribution models should considerably improve conservation recommendations for Taiwan. For example, almost all our analyses point to an important avian hotspot in Taiwan's northeastern Nan-ao mountainous areas even though sampling efforts in that region have been relatively moderate (Wu et al. 2013).

Our analyses are a major advance for Taiwan's conservation efforts because not only were we able to produce the first almost-complete avian hotspot maps for Taiwan, but we were also able to test how well Taiwan's protected areas cover these hotspots. Almost all of our species richness and hotspot analyses revealed that mountainous regions of Taiwan hold most of Taiwan's avian biodiversity. Previous studies showed a humpshaped relationship between avian species richness and Taiwan's elevation gradient, meaning that the highest species richness was found in mid-elevation forests (Koh and Lee 2003; Shiu and Lee 2003; Hsu et al. 2004; Lee et al. 2004; Ding et al. 2005; Koh et al. 2006b), which is unlike the species richness pattern found on Hainan Island, China in the northwestern South China Sea

Table 3 Percentage overlap between different hotspot criteria using the $5 \%$ most species-rich grid cells

\begin{tabular}{lllll}
\hline & Total species richness & Endemic species richness & Threatened species richness & Rare species richness \\
\hline Total species richness & - & $512(1.4 \%, 34.8 \%, 33.7 \%)$ & $742(2.1 \%, 50.4 \%, 47.1 \%)$ & $58(0.2 \%, 3.9 \%, 25.3 \%)$ \\
Endemic species richness & $1,356(3.8 \%, 51.2 \%, 61.6 \%)$ & - & $832(2.3 \%, 54.8 \%, 52.8 \%)$ & $91(0.3 \%, 6.0 \%, 39.8 \%)$ \\
Threatened species richness & $1,474(4.1 \%, 72.4 \%, 67.0 \%)$ & $1,691(4.7 \%, 83.1 \%, 63.9 \%)$ & - & $189(0.5 \%, 12.0 \%, 82.5 \%)$ \\
Rare species richness & $948(4.6 \%, 33.2 \%, 43.1 \%)$ & $1,881(5.2 \%, 65.9 \%, 71.1 \%)$ & $1,263(3.5 \%, 44.2 \%, 62.0 \%)$ & - \\
\hline
\end{tabular}

In each cell, the number of grid cells which overlapped for both hotspot criteria given in the row and column is given. In the following parentheses, we calculated the percentage for this number divided by (1) the total number of grid cells of the study area (36,022 grid cells), (2) the number of grid cells falling into the hotspot criterion in the row, and (3) the number of grid cells falling into the hotspot criterion in the column. To the upper right of the diagonal, this calculation was done for grid cells which were determined to be the $5 \%$ most species-rich grid cells within the entire study area (Table 1, Figure 6 ), and to the lower left of the diagonal, the calculation was done for grid cells which were determined to be the $5 \%$ most species-rich grid cells outside of protected areas (Table 1 , Figure 7). 


\begin{tabular}{|c|c|c|c|c|}
\hline $\begin{array}{l}\text { Hotspot } \\
\text { criteria } \\
\text { fulfilled }\end{array}$ & $\begin{array}{l}\text { Hotspot } \\
\text { criteria } \\
\text { combination }\end{array}$ & $\begin{array}{l}\text { Number } \\
\text { of grid } \\
\text { cells }\end{array}$ & Percentage & Total \\
\hline 4 & T-E-Th-R & 47 & 1.60 & 47 (1.60\%) \\
\hline \multirow[t]{4}{*}{3} & T-E-Th & 378 & 12.85 & $428(14.55 \%)$ \\
\hline & T-E-R & 1 & 0.03 & \\
\hline & T-Th-R & 10 & 0.34 & \\
\hline & E-Th-R & 39 & 1.33 & \\
\hline \multirow[t]{6}{*}{2} & T-E & 86 & 2.92 & $858(29.16 \%)$ \\
\hline & T-Th & 307 & 10.44 & \\
\hline & $\mathrm{T}-\mathrm{R}$ & 0 & 0.00 & \\
\hline & E-Th & 368 & 12.51 & \\
\hline & $\mathrm{E}-\mathrm{R}$ & 4 & 0.14 & \\
\hline & Th-R & 93 & 3.16 & \\
\hline \multirow[t]{4}{*}{1} & T & 643 & 21.86 & 1,609 (54.69\%) \\
\hline & E & 596 & 20.26 & \\
\hline & Th & 335 & 11.39 & \\
\hline & $\mathrm{R}$ & 35 & 1.19 & \\
\hline Total & & 2,942 & 100.00 & \\
\hline
\end{tabular}

The second column shows specific combinations of hotspot criteria: total species richness $(T)$, endemic species richness $(E)$, threatened species richness (Th), and rare species richness (R). For example, the criterion ' $T-E^{\prime}$ ' means that the grid cells fulfilled the total and endemic hotspot criterion but not the threatened or rare hotspot criteria. The third column gives the number of grid cells fulfilling the criteria combination given in the second column. The fourth column is the percentage in relation to all hotspot grid cells (a total of 2,942 grid cells which fulfilled at least one hotspot criterion). The fifth column gives the number of grid cells (and percentage) fulfilling the hotspot criteria (or criterion) given in the first column.

(Zou et al. 2012). Therefore, it is not surprising that our analyses confirmed that species richness and hotspots were mostly found in mountainous areas.

However, it is quite conceivable that the almostcomplete transformation of Taiwan's lowland areas led to many species becoming extinct there, meaning that the hump-shaped relationship is a human-induced artifact. Previous studies demonstrated a negative relationship between the human population density and avian species richness in Taiwan (Lee et al. 2004; Koh et al. 2006a). Avian hotspots may thus have existed in the lowlands before humans transformed those areas and could possibly be reestablished if substantial lowland areas were restored to more natural conditions.

One of our hotspot analyses, namely rare species richness, pinpointed unprotected areas in the southwestern lowlands (Figures 5 and 7) which had not been emphasized by previous studies (Nieh 1999; Ko et al. 2009b) and could form the basis for such an attempt to restore lost biodiversity. However, this is unlikely to happen in the near future because of the high human population density there. Consequently, short-term conservation efforts should focus on protecting those species-rich hotspots pinpointed in Figure 7 which are still unprotected and occur in areas with relatively intact natural habitats. The reason for areas in the southwestern lowlands being selected by this analysis but not by the others is that several rare species occur in the southwestern lowlands of Taiwan (as also discussed below).

The only substantial and still relatively intact region which our analyses consistently highlighted as an important avian hotspot was a large area of unprotected and relatively intact forested habitat in Taiwan's northeast (Figures 6 and 7) which should become a high priority for future fieldwork and conservation efforts. Other unprotected areas with high conservation value are basically spatial extensions of areas already protected in the central and southern mountains, whereby different hotspot criteria pointed to somewhat different areas. Such differential prioritization should be expected because different hotspot criteria only partially overlap and sometimes hardly at all (Tables 3 and 4, Figures 6 and 7). For example, the overlap (also called 'congruence') between hotspots of total species richness and endemic species richness was only $34.8 \%$ (for total species richness) to $33.7 \%$ (for endemic species richness) (Table 3), which goes against the hypothesis that endemic hotspot richness might be a good indicator of total hotspot richness in Taiwan (Nieh 1999; Ko et al. 2009b). Therefore, to protect areas in Taiwan based on only one hotspot criterion would not necessarily result in the protection of areas deemed important using other hotspot criteria.

Since we did not test macroecological hypotheses in this paper, future studies should investigate macroecological correlates to the different species richness patterns which are documented in this study. However, such correlative studies will always suffer from the absence of historical data to test real cause-and-effect relationships: an example is the mid-elevation species hump due to a mid-domain effect (Colwell and Lees 2000) or the almost-complete anthropogenic alteration of Taiwan's lowland ecosystems (Shiu and Lee 2003; Lee et al. 2004; Koh et al. 2006a). For the purposes of conservation, however, it is sufficient to highlight important areas which should be the target of more intensive field work and conservation management.

Our study included a few more endemic species than previous studies. Specifically, we included the Taiwan Barbet Megalaima nuchalis and Taiwan Hwamei Garrulax taewanus which were not included by Nieh (1999) and Ko et al. (2009b); we further included the Taiwan BushWarbler Bradypterus alishanensis which was not included by Nieh (1999), and we also included Styan's Bulbul Pycnonotus taivanus which was not included by Ko et al. (2009b). Nevertheless, our results mostly confirmed those of previous studies. Our mean and standard deviation for the elevation of endemic species hotspots was 2,016 \pm 
$463.0 \mathrm{~m}$, while Nieh (1999) reported 1,941 $\pm 602.5 \mathrm{~m}$, and Ko et al. (2009b) reported 1,917 $\pm 437.8 \mathrm{~m}$. Furthermore, a visual comparison of our Figure 3B with figure thirty of Nieh (1999) and figure five in Ko et al. (2009b) shows a very good agreement, with the exception that our analysis highlighted more hotspots in southern Taiwan, and Nieh (1999) failed to pick out the northeastern Nan-ao mountainous areas. This could have been due to differences in the lists of endemic species, especially lowland species, as described above. Our analysis is therefore important in that it confirms some previous results and also highlights additional previously undetected areas of high species richness. Furthermore, our results are much more relevant as they are based on a much more complete set of species.

Our results are also relevant to hotspot studies globally. Most importantly, different hotspot criteria overlapped only partially and sometimes hardly at all in our analysis (see above), thereby confirming previous results of limited overlap or congruence (e.g., Prendergast et al. 1993; Moritz et al. 2001; Lund and Rahbek 2002; Moore et al. 2003; Ho 2005; Orme et al. 2005; Grenyer et al. 2006; Franco et al. 2009; van Weerd and de Haes 2010; but see Kerr 1997; Mac Nally et al. 2002). This lack of congruence was especially evident at smaller spatial scales (Lund and Rahbek 2002; Grenyer et al. 2006; Franco et al. 2009; van Weerd and de Haes 2010). Since our results were based on a very fine scale of a $1 \times 1-\mathrm{km}$ grid size, they are supportive of this trend. Therefore, no subset of species could be taken to be a generally good indicator for all the species within a taxon, nor could a taxon be taken as good indicator for other taxa, especially at smaller spatial scales. Rather, as many taxa and as many criteria as possible need to be analyzed to make value judgments about how to prioritize our findings (Prendergast et al. 1993; Chen 2007; Moilanen et al. 2009; see also our suggestions for further studies in Taiwan below). Unlike most other hotspot studies, we eliminated hotspots from inside protected areas in our third analysis (Figures 2, 3, 4, 5C, and 7) which highlighted areas in need of future protection. Such an analysis should be considered for hotspot studies in many other regions. Finally, we cannot overemphasize the importance of using species distribution models instead of raw locational data to achieve reliable results for undersampled regions (e.g., Franco et al. 2009).

The relatively high number of endemic species is one of Taiwan's outstanding biodiversity features. The existing protected areas network, as it is mostly found in mountainous areas should, according to our analyses, protect most endemic species rather well as they are also concentrated in the mountains (Figure 3) with a few notable exceptions (the Taiwan Barbet, Formosan Blue Magpie Urocissa caerulea, Taiwan Hwamei, and Styan's Bulbul). However, this could change if mountain species are forced to migrate upwards because of climate change (Ko 2010; Chien et al. 2012). Moreover, although percentages of hotspot criteria covered by 'low-to-high' protection were rather high $(48.5 \%$ to $87.2 \%$, Table 2$)$, a large portion of those percentages come from major wildlife habitats, which are in the lowest protection category. For the highest protection category, namely national parks, percentages were much lower $(12.7 \%$ to $19.2 \%$, Table 2). Therefore, we strongly support upgrading the protection status of some of the less wellprotected areas and establishing some completely new protected areas, especially in the northeastern mountains (Figures 6 and 7).

Hotspots are just one, albeit important, criterion for establishing conservation priorities. Future studies need to complement this study in a number of ways: (1) Other criteria, foremost among them would be complementarity analyses, need to be included in conservation recommendations (Lehtomäki et al. 2009; Moilanen et al. 2009; Visconti et al. 2010); such analyses would most likely highlight more of Taiwan's lowland areas as priority sites, e.g., sites occupied by threatened species such as the Fairy Pitta (Ko et al. 2009a). An obvious drawback of hotspot analyses is that they may leave out areas important to rare species, and Taiwan's lowland species are rare exactly because their habitats have already been almost completely destroyed. Therefore, complementarity analyses are required to pinpoint lowland areas of conservation importance. (2) Other taxa, such as mammals, insects, and plants, need to be incorporated in the analyses to make conclusions more relevant to all of Taiwan's biodiversity. As hotspots for different taxa frequently do not overlap (i.e., are not congruent, see Prendergast et al. 1993; Moritz et al. 2001; Lund and Rahbek 2002; Moore et al. 2003; Ho 2005; Orme et al. 2005; Grenyer et al. 2006; Franco et al. 2009; van Weerd and de Haes 2010), the more taxa that are included in the analyses, the more comprehensive the resulting recommendations will be. One obvious problem with including other taxa is that reliable distribution models need to be based on a minimum number of observation records (usually $>20$ to 30 ) which might not be available for many other taxa (e.g., cryptic mammals and undersampled beetles). Therefore, we must caution against the use of our methodology if sample sizes are too small or sample coverage too biased. In such cases, locational records themselves should be used, while the results of distribution models should only be used with great care (Wisz et al. 2008; Costa et al. 2010). Nevertheless, once a sufficient sample size and reliable sample coverage have been achieved (see summary in Wu et al. 2012), the use of distribution models should overall result in much better conservation recommendations because distribution models fill in gaps of sampling 
coverage; in other words, much limited time and resources can be saved by not having to determine a species' presence or absence within every possible grid cell. (3) Potential future land use and climate change effects should be investigated to safeguard elevational corridors, multiple populations, and viable ecological niches (Polasky 2008; Klein et al. 2009; Carroll et al. 2010; Kharouba and Kerr 2010; Chien et al. 2012). In Taiwan, most high-elevation species are probably endangered by climate change, but low-elevation species may also be endangered if they cannot utilize corridors to migrate upwards. Furthermore, some lowland species (e.g., Bluebreasted quail Coturnix chinensis, Pheasant-tailed Jacana Hydrophasianus chirurgus, and Australasian Grass Owl Tyto longimembris) are already close to extinction because of continuous land use conversion and will likely become extinct if their few remaining habitats are not urgently protected.

Distribution modeling and geographic information systems allow researchers to pinpoint areas of high species richness, but they also allow calculation of the coverage provided by the already existing protected area network. Currently, Taiwan's protected areas cover almost 30\% of the distributional ranges of the 116 bird species that we modeled, which drops to $16.9 \%$ for medium-to-high and to $12.5 \%$ for the highest protection but with much variation between species (Wu et al. 2013). While this is not bad compared to many other regions of the world, it is still questionable whether most species can survive in case they are confronted with future land use and climate changes. To protect Taiwan's unique avifauna, further analyses as outlined above are needed, and conservation recommendations need to be turned into actual conservation measures.

\section{Conclusions}

We present a hotspot analysis of Taiwanese breeding birds with sufficient sampling coverage for distribution modeling. Almost all of the species richness and hotspot analyses revealed that the mountainous regions of Taiwan hold most of Taiwan's avian biodiversity. The only substantial unprotected region which was consistently highlighted as an important avian hotspot is a large area of unprotected mountains in Taiwan's northeast (mountain regions around Nan-ao) which should become a high priority for future fieldwork and conservation efforts. In contrast, other unprotected areas of high conservation value were just spatial extensions of areas already protected in the central and southern mountains. We also found that different hotspot criteria only partially overlapped and sometimes barely at all. Therefore, to protect areas based only on one hotspot criterion (e.g., total species richness) would not protect areas based on other hotspot criteria (e.g., endemic species richness, threatened species richness, or rare species richness) in Taiwan.

\section{Competing interests}

The authors declare that they have no competing interests.

\section{Authors' contributions}

PFL initiated the idea, built the bird and environment database, and participated in the writing of this paper. TYW built the avian distribution database, carried out the analysis, and drafted the manuscript. BAW carried out the analysis and completed the final draft. YHC built distribution models, and RSL provided avian data and also drafted the manuscript. All authors read and approved the final manuscript.

\section{Acknowledgements}

We thank CJ Ko, WJ Chih, and CY Peng for providing additional distribution data and WJ Chih for comments on bird statuses. We thank two anonymous reviewers for their helpful comments. This work was partially supported by the National Park Division of the Construction and Planning Agency, Ministry of the Interior, Taiwan and the National Science Council, Taiwan under grants NSC97-2321-B-002-032, NSC99-2621-B-002-003, NSC99-2811-B-329-001, NSC99-2321-B-329-001-MY2, and NSC101-2631-H-002-005.

\section{Author details}

${ }^{1}$ Institute of Ecology and Evolutionary Biology, National Taiwan University, Taipei 106, Taiwan. ${ }^{2}$ College of International Studies, National Pingtung University of Science and Technology, Neipu, Pingtung 91201, Taiwan. ${ }^{3}$ Master Program in Global Health and Development, College of Public Health and Nutrition, Taipei Medical University, 250 Wu-Hsing St, Taipei 110, Taiwan. ${ }^{4}$ Endemic Species Research Institute, 1 Ming-Shen East Road, Jiji, Nantou 552, Taiwan. ${ }^{5}$ Biodiversity Research Center, National Taiwan University, Taipei 106, Taiwan.

Received: 9 April 2012 Accepted: 19 February 2013

Published: 4 October 2013

\section{References}

Araújo MB, New M (2007) Ensemble forecasting of species distributions. Trends Ecol Evol 22:42-47

Austin MP (2002) Spatial prediction of species distribution: an interface between ecological theory and statistical modelling. Ecol Model 157:101-118

Butchart SHM, Walpole M, Collen B, van Strien A, Scharlemann JPW, Almond REA, Baillie JEM, Bomhard B, Brown C, Bruno J, Carpenter KE, Carr GM, Chanson J, Chenery AM, Csirke J, Davidson NC, Dentener F, Foster M, Galli A, Galloway JN, Genovesi P, Gregory RD, Hockings M, Kapos V, Lamarque JF, Leverington F, Loh J, McGeoch MA, McRae L, Minasyan A, et al (2010) Global biodiversity: indicators of recent declines. Science 328:1164-1168

Callicott JB, Rozzi R, Delgado L, Monticino M, Acevedo M, Harcombe P (2007) Biocomplexity and conservation of biodiversity hotspots: three case studies from the Americas. Phil Trans R Soc B 362:321-333

Carroll C, Dunk JR, Moilanen A (2010) Optimizing resiliency of reserve networks to climate change: multispecies conservation planning in the Pacific Northwest, USA. Global Change Biol 16:891-904

Ceballos G, Ehrlich PR (2006) Global mammal distributions, biodiversity hotspots, and conservation. Proc Natl Acad Sci USA 103:19374-19379

Chen YH (2007) Prioritizing avian conservation areas in China by hotspot scoring, heuristics and optimisation. Acta Ornithol 42:119-128

Chien YL, Shaw D, Wang TH, Lee PF, Ko CY (2012) Cost-effective reserve network dynamic planning strategies for biodiversity conservation under the climate change. In: 2nd Congress of the East Asian Association of Environmental and Resource Economics (EAAERE), Bandung., 2-4 February 2012

Federation CWB (2010) The checklist of the birds of Taiwan. Feather 23:66-95 (in Chinese)

Colwell RK, Lees DC (2000) The mid-domain effect: geometric constraints on the geography of species richness. Trends Ecol Evol 15:70-76

Costa GC, Nogueira C, Machado RB, Colli GR (2010) Sampling bias and the use of ecological niche modeling in conservation planning: a field evaluation in a biodiversity hotspot. Biodivers Conserv 19:883-899

Ding TS, Yuan HW, Geng S, Lin YS, Lee PF (2005) Energy flux, body size and density in relation to bird species richness along an elevational gradient in Taiwan. Global Ecol Biogeogr 14:299-306 
Ding T-S, Yuan H-W, Geng S, Koh C-N, Lee P-F (2006) Macro-scale bird species richness patterns of the East Asian mainland and islands: energy, area and isolation. J Biogeogr 33:683-693

Dobson AP, Rodriguez JP, Roberts WM, Wilcove DS (1997) Geographic distribution of endangered species in the United States. Science 275:550-553

Fang WH (2008) The complete field guide of the birds of Taiwan. Owl Publishing House, Taipei (in Chinese)

Fielding AH, Bell JF (1997) A review of methods for the assessment of prediction errors in conservation presence/absence models. Environ Conserv 24:38-49

Franco AMA, Anderson BJ, Roy DB, Gillings S, Fox R, Moilanen A, Thomas CD (2009) Surrogacy and persistence in reserve selection: landscape prioritization for multiple taxa in Britain. J Appl Ecol 46:82-91

Freeman EA, Moisen GG (2008) A comparison of the performance of threshold criteria for binary classification in terms of predicted prevalence and kappa. Ecol Model 217:48-58

Garcia A (2006) Using ecological niche modelling to identify diversity hotspots for the herpetofauna of Pacific lowlands and adjacent interior valleys of Mexico. Biol Conserv 130:25-46

Grenyer R, Orme CDL, Jackson SF, Thomas GH, Davies RG, Davies TJ, Jones KE, Olson VA, Ridgely RS, Rasmussen PC, Ding TS, Bennett PM, Blackburn TM, Gaston KJ, Gittleman JL, Owens IPF (2006) Global distribution and conservation of rare and threatened vertebrates. Nature 444:93-96

Hernandez PA, Graham CH, Master LL, Albert DL (2006) The effect of sample size and species characteristics on performance of different species distribution modeling methods. Ecography 29:773-785

Hirzel AH, Hausser J, Chessel D, Perrin N (2002) Ecological-niche factor analysis: how to compute habitat-suitability maps without absence data? Ecology 83:2027-2036

Ho L-J (2005) Selections and analyses of avian biodiversity hotspots in East Asia. National Taiwan University, Master's thesis (in Chinese)

Hsu FH, Yao CT, Lin SRS, Yang CC, Lai SJ (2004) Avian species composition and distribution along elevation gradient in the southern Taiwan. Endem Spec Res 6(2):41-66 (in Chinese)

Huang PL (2001) Distribution pattern of breeding birds in northern Taiwan. National Taiwan University, Taipei, Master's thesis

IUCN (2011) The IUCN Red List of threatened species. http://www.iucnredlist.org/. Accessed March 2011

Jenkins CN, Alves MAS, Pimm SL (2010) Avian conservation priorities in a topranked biodiversity hotspot. Biol Conserv 143:992-998

Johnson RA, Wichern DW (2007) Applied multivariate statistical analysis, 6th edn. Prentice-Hall International, Upper Saddle River, NJ

Kerr JT (1997) Species richness, endemism, and the choice of areas for conservation. Conserv Biol 11:1094-1100

Kharouba HM, Kerr JT (2010) Just passing through: global change and the conservation of biodiversity in protected areas. Biol Conserv 143:1094-1101

Klein C, Wilson K, Watts M, Stein J, Berry S, Carwardine J, Smith MS, Mackey B, Possingham H (2009) Incorporating ecological and evolutionary processes into continental-scale conservation planning. Ecol Appl 19:206-217

Ko CJ (2004) The relationship between avian community and forest landscapes in Guanwu. National Taiwan University, Taipei, Taiwan. Master's thesis (in Chinese)

Ko CY (2010) Current biodiversity and future distributions of endemic bird species in Taiwan. National Taiwan University, Taipei, Doctoral thesis

Ko CY, Lee PF, Bai ML, Lin RS (2009a) A rule-based species predictive model for the vulnerable Fairy Pitta (Pitta nympha) in Taiwan. Taiwania 54:28-36

Ko CY, Lin RS, Ding TS, Hsieh CH, Lee PF (2009b) Identifying biodiversity hotspots by predictive models: a case study using Taiwan's endemic bird species. Zool Stud 48:418-431

Koh CN, Lee PF (2003) Elevational gradients in breeding birds in northern Taiwan. Taiwan J For Sci 18:349-361 (in Chinese)

Koh CN, Lee PF, Lin RS (2006a) Bird species richness patterns of northern Taiwan: primary productivity, human population density, and habitat heterogeneity. Divers Distrib 12:546-554

Koh CN, Lee PF, Wu SH (2006b) Does the distribution of breeding bird species richness in Taiwan follow the mid-domain effect? Taiwania 51:108-116

Lee PF, Liao CY, Lee YC, Pan YH, Fu WH, Chen HW (1997) An ecological and environmental GIS database for Taiwan. National Taiwan University, Taipei, Department of Zoology (in Chinese)

Lee PF, Lue KY, Lee YC, Hsieh CC, Pan YH, Chen HW, Pan TC, Ding TS (1998) Taiwan wildlife distribution database. Council of Agriculture, Executive Yuan, Taipei (in Chinese)
Lee PF, Ding TS, Hsu FH, Geng S (2004) Breeding bird species richness in Taiwan: distribution on gradients of elevation, primary productivity and urbanization. J Biogeogr 31:307-314

Lehtomäki J, Tomppo E, Kuokkanen P, Hanski I, Moilanen A (2009) Applying spatial conservation prioritization software and high-resolution GIS data to a national-scale study in forest conservation. For Ecol Manage 258:2439-2449

Liao CY (1997) The spatial distribution and predictive model of Timaliinae in Taiwan. National Taiwan University, Taipei, Master's thesis (in Chinese)

Lund MP, Rahbek C (2002) Cross-taxon congruence in complementarity and conservation of temperate biodiversity. Anim Conserv 5:163-171

Mac Nally R, Bennett AF, Brown GW, Lumsden LF, Yen A, Hinkley S, Lillywhite P, Ward D (2002) How well do ecosystem-based planning units represent different components of biodiversity? Ecol Appl 12:900-912

Millennium Ecosystem Assessment (2005) Ecosystems and human well-being: biodiversity synthesis. World Resources Institute, Washington, DC

Moilanen A, Wilson KA, Possingham H (eds) (2009) Spatial conservation prioritization: quantitative methods and computational tools. Oxford University Press, New York

Moore JL, Balmford A, Brooks T, Burgess ND, Hansen LA, Rahbek C, Williams PH (2003) Performance of sub-Saharan vertebrates as indicator groups for conservation priority areas for conservation. Conserv Biol 17:207-218

Moritz C, Richardson KS, Ferrier S, Monteith GB, Stanisic J, Williams SE, Whiffin T (2001) Biogeographical concordance and efficiency of taxon indicators for establishing conservation priority in a tropical rainforest biota. Proc R Soc Lond B 268:1875-1881

Myers N (1988) Threatened biotas: "hot spots" in tropical forests. Environmentalist 8:187-208

Myers N, Mittermeier RA, Mittermeier CG, da Fonseca GAB, Kent J (2000) Biodiversity hotspots for conservation priorities. Nature 403:853-858

Nieh C-H (1999) Species richness pattern of breeding birds in Taiwan. National Taiwan University, Taipei, Master's thesis (in Chinese)

Orme CDL, Davies RG, Burgess M, Eigenbrod F, Pickup N, Olson VA, Webster AJ, Ding TS, Rasmussen PC, Ridgely RS, Stattersfield AJ, Bennett PM, Blackburn TM, Gaston KJ, Owens IPF (2005) Global hotspots of species richness are not congruent with endemism or threat. Nature 436:1016-1019

Peng CY (2008) Temporal and spatial variations of bird assemblage in the Taroko National Park. National Taiwan University, Taipei, Master's thesis (in Chinese)

Phillips SJ, Anderson RP, Schapired RE (2006) Maximum entropy modeling of species geographic distributions. Ecol Model 190:231-259

Polasky S (2008) Why conservation planning needs socioeconomic data. Proc Natl Acad Sci USA 105:6505-6506

Prendergast JR, Quinn RM, Lawton JH, Eversham BC, Gibbons DW (1993) Rare species, the coincidence of diversity hotspots and conservation strategies. Nature 365:335-337

Samson FB, Knopf FL (1993) Managing biological diversity. Wildl Soc Bull 21:509-514

Schouten MA, Barendregt A, Verweij PA, Kalkman VJ, Kleukers RMJC, Lenders HJR, Siebel HN (2010) Defining hotspots of characteristic species for multiple taxonomic groups in the Netherlands. Biodivers Conserv 19:2517-2536

Severinghaus LL (1994) The zoogeography and biodiversity of birds in Taiwan. In: Peng $\mathrm{Cl}$, Chou CH (eds) Biodiversity and terrestrial ecosystems. Institute of Botany, Academia Sinica Monograph Series, vol. 14. 245-258 In: Biodiversity and Terrestrial Ecosystems. eds. C. I. Peng and C. H. Chou, Institute of Botany, Academia Sinica Monograph Series No. 14. Academia Sinica, Tapei, pp 245-258

Severinghaus LL, Ding TS, Fang WH, Lin WH, Tsai MC, Yen CW (2010) The avifauna of Taiwan, 1st edn. Forestry Bureau, Council of Agriculture, Executive Yuan, Taipei (in Chinese)

Shao KT, Peng Cl, Wu WJ (2008) 2008 Taiwan species diversity - I. Research and status, Biodiversity Research Center, Academia Sinica, Taipei (in Chinese)

Shiu HJ, Lee PF (2003) Seasonal variation in bird species richness along elevational gradients in Taiwan. Acta Zool Taiwan 14:1-21

Stockwell DRB, Beach JH, Stewart A, Vorontsov G, Vieglais D, Pereira RS (2006) The use of the GARP genetic algorithm and internet grid computing in the lifemapper world atlas of species biodiversity. Ecol Model 195:139-145

van Weerd M, de Haes HAU (2010) Cross-taxon congruence in tree, bird and bat species distributions at a moderate spatial scale across four tropical forest types in the Philippines. Biodivers Conserv 19:3393-3411

Visconti P, Pressey RL, Segan DB, Wintle BA (2010) Conservation planning with dynamic threats: the role of spatial design and priority setting for species' persistence. Biol Conserv 143:756-767 

Modelling the winter distribution of a rare and endangered migrant, the aquatic warbler Acrocephalus paludicola. Ibis 149:701-714

Walther BA, van Niekerk A, Thuiller W, Baumann S, Dean WRJ, de Bruijn B, Gutteridge K, Jones PJ, Nikolaus G, Pearson DJ, Robinson SP, Salewski V, Schäffer N, Taylor PB, Tushabe H, Williams PH, Rahbek C (2010) A database of Western Palearctic birds migrating within Africa to guide conservation decisions. In: Harebottle DM, Craig AJFK, Anderson MD, Rakotomanana H, Muchai M (eds) Proceedings of the 12th Pan-African Ornithological Congress, Western Cape, September 2008. Animal Demography Unit, Cape Town, pp 50-72

Walther BA, Larigauderie A, Loreau M (2011a) Diversitas: biodiversity science integrating research and policy for human well-being. In: Brauch HG, Spring ÚO, Mesjasz C (eds) Coping with global environmental change, disasters and security - threats, challenges, vulnerabilities and risks. Springer-Verlag, Berlin, pp 1235-1248

Walther BA, Wu TY, Chen YH, Lin RS, Lee PF (2011b) Using species distribution models to assess the rarity and conservation status of Taiwanese birds. Taiwan J Biodivers 13:295-322

Williams P, Gibbons D, Margules C, Rebelo A, Humphries C, Pressey R (1996) A comparison of richness hotspots, rarity hotspots, and complementary areas for conserving diversity of British birds. Conserv Biol 10:155-174

Wisz MS, Hijmans RJ, Li J, Peterson AT, Graham CH, Guisan A (2008) Effects of sample size on the performance of species distribution models. Divers Distrib 14:763-773

Wu TY, Lee PF, Lin RS, Wu JL, Walther BA (2012) Modeling the distribution of rare or cryptic bird species of Taiwan. Taiwania 57:342-358

Wu TY, Walther BA, Chen YH, Lin RS, Lee PF (2013) Reassessment of the conservation status of Taiwanese birds: how distribution modelling can help species conservation. Bird Conserv Intl. doi:10.1017/S0959270913000336

Zou FS, Chen GZ, Yang QF, Li YD (2012) Bird species richness along an elevational gradient in a forest at Jianfengling, Hainan Island, China. Zool Stud 51:362-371

doi:10.1186/1810-522X-52-29

Cite this article as: Wu et al:: Hotspot analysis of Taiwanese breeding birds to determine gaps in the protected area network. Zoological Studies 2013 52:29.

\section{Submit your manuscript to a SpringerOpen ${ }^{\odot}$ journal and benefit from:}

- Convenient online submission

- Rigorous peer review

- Immediate publication on acceptance

- Open access: articles freely available online

- High visibility within the field

- Retaining the copyright to your article 